\title{
The Effect of Technological Parameters on the Foaming of Injection Moulded Recycled PET
}

\author{
B. Molnár \\ Budapest University of Technology and Economics \\ Department of Polymer Engineering \\ H-1111 Budapest, Múegyetem rkp. 3., Hungary \\ E-mail: frederik.moriente@gmail.com
}

Abstract: The foaming of regranulate made from recycled PET bottles was examined, varying two important technological parameters: holding pressure, and the amount of material injected into the mould cavity, which was controlled with the switchover point. It was shown with optical and density tests that these parameters have a significant effect on the foam structure, which greatly influences mechanical properties.

Keywords: recycled PET, injection moulding, foaming

\section{Introduction}

One of the largest branches of polymer industry is the packaging industry, and within this the use and recycling of PET bottles is gaining more and more prominence. In 2010, 97.1\% of PET was used for packaging in Hungary, while the share of PET in all packaging was $20.6 \%$. These bottles have a short life cycle, and are mostly used only once so they generate a massive amount of waste. This waste can be recycled in several ways: most commonly as a clothes industry raw material or in the form of plastic strips or sheets, but its use for plastic bottles is also more and more widespread $[1,2]$.

Another possibility is reuse as engineering plastic. PET is an excellent engineering plastic (hard, rigid, highly wear-proof, good dimensional stability, physiologically neutral, resistant to weak acids and alkalis, little water absorption). Although its characteristics degrade during recycling, it can still serve as a good alternative to various polymers, and with the proper preparation it can be used for the original purpose (e.g. manufacturing bottles from bottles). In addition various "value-adding" processes can be applied, such as foaming, using special additives, or making the plastic flame retardant $[3,4]$.

Foaming is a common procedure in the plastic industry. It can be a separate technology (e.g. manufacturing EPS foam), or part of another manufacturing process (e.g. injection moulding, extrusion). There are also various classifications (according to foam structure, density or manufacturing procedure). The procedures can be classified into three groups according to manufacturing process: 
- mechanical: the gas is mixed with the plastic mechanically;

- $\quad$ physical: two types are possible

- gas is blown into the melt or

- a foaming agent of low boiling point is added, which creates the foaming gas through a change of state;

- chemical: the foaming gas is produced with a chemical reaction $[5,6]$.

There are more and more articles about the foaming of PET in the literature. These describe various methods (physical/chemical extrusion foaming, creating a sandwich structure, injection moulding, hot forming, etc.). Most extrusion and injection moulding experiments use physical foaming, which produces a more uniform foam structure and lower density (down to $0.2-0.5 \mathrm{~g} / \mathrm{cm}^{3}$ ) can be achieved than with chemical foaming, but separate equipment is needed for the introduction of the high-pressure gas. Chemical foaming on the other hand can be done on a normal extruder/injection moulding machine without additional equipment. I used chemical foaming in my experiments [7].

In the foam injection moulding of recycled PET the viscosity of the polymer is important. This is determined not only by processing parameters but also by molecular structure. In secondary materials molecule length decreases considerably, which can be attributed to multiple processing. This leads to a decrease in the intrinsic viscosity of the melt, and the processability of the material is decreased. This can be dramatically improved by adding chain extenders. These materials connect to the ends of several polymer chains, this way increasing their length and the number of branches, thus increasing intrinsic viscosity of the material, giving it better processability [8-11].

The goal of the experiment is to produce an engineering plastic part from recycled PET using foam injection moulding, and to reveal the connection between the holding pressure and switchover point, and the physical and mechanical properties of the product.

\section{Description of the equipment, raw materials and technology}

The regranulate used to manufacture the product were made from recycled and ground PET. Before processing the granules were dried at 50 degrees Celsius for 6 hours in each case. CESA Extend chain extender (Clariant) was added, its proportion was $2 \%$. The foaming agent was Safoam RPC-40 (Reedy International). Injection moulding was done with an Arburg Allrounder Advance 370S 700-290 injection moulding machine. The polymer was ground and recycled PET, turned into granules. In the injection moulding cycle I used a $0.1 \mathrm{~mm}$ mould opening after holding pressure, as a result of which the surface of the product did not get into contact with the mould and so no external pressure was exerted on it, which could have inhibited foaming. This led to better foaming. The samples were manufactured with three different holding pressure profiles. Table 1 contains the main settings and technological parameters used during manufacturing, Table 2. contains the holding pressure profiles and Table 3 . contains the switchover point values. 
Table 1. Main technological parameters and holding pressure profiles

\begin{tabular}{|c|c|c|c|c|}
\hline Holding pressure profile & & High & Medium & Low \\
\hline Raw material & & \multicolumn{3}{|c|}{ RPET regranulate } \\
\hline Foaming agent & & \multicolumn{3}{|c|}{ 4\% Safoam RPC-40 } \\
\hline Chain extender & & \multicolumn{3}{|c|}{$2 \%$ CESA Extend } \\
\hline Drying temperature/time & {$\left[{ }^{\circ} \mathrm{C}\right] /[\mathrm{h}]$} & \multicolumn{3}{|c|}{$50 / 4$} \\
\hline Clamp force & {$[\mathrm{kN}]$} & \multicolumn{3}{|c|}{175} \\
\hline Mould opening & {$[\mathrm{mm}]$} & \multicolumn{3}{|c|}{0,1} \\
\hline Delay (residual cooling time) & {$[\mathrm{s}]$} & \multicolumn{3}{|c|}{20} \\
\hline Nozzle temperature & {$\left[{ }^{\circ} \mathrm{C}\right]$} & \multicolumn{3}{|c|}{275} \\
\hline Mould temperature & {$\left[{ }^{\circ} \mathrm{C}\right]$} & \multicolumn{3}{|c|}{50} \\
\hline
\end{tabular}

Table 2. Used holding pressure profiles

\begin{tabular}{|c|c|c|c|c|}
\hline $\begin{array}{c}\text { Holding pressure } \\
\text { profile }\end{array}$ & High & medium & Low \\
\hline Switchover point & {$\left[\mathrm{cm}^{3}\right]$} & \multicolumn{3}{|c|}{14} \\
\hline $\begin{array}{c}\text { Holding pressure } \\
\text { profile } \\
\left(\boldsymbol{p}_{1}-\boldsymbol{t}_{1}-\boldsymbol{p}_{2}-\boldsymbol{t}_{2}-\boldsymbol{p}_{3}\right)\end{array}$ & $\begin{array}{c}{[\mathrm{bar}]-[\mathrm{s}]-[\mathrm{bar}]-} \\
-[\mathrm{s}]-[\mathrm{bar}]\end{array}$ & $\begin{array}{c}600-6-400- \\
-2-50\end{array}$ & $\begin{array}{c}600-3-400- \\
-1-50\end{array}$ & $\begin{array}{c}400-2-200- \\
-1-50\end{array}$ \\
\hline
\end{tabular}

Table 3. Used switchover points

\begin{tabular}{|c|c|c|c|c|}
\hline Holding pressure [bar]/[s]/[bar]/[s]/[bar] & \multicolumn{4}{|c|}{$400 / 2 / 200 / 1 / 50$} \\
\hline Shot volume $\left[\mathrm{cm}^{3}\right]$ & \multicolumn{4}{|c|}{40} \\
\hline Switchover point $\left[\mathrm{cm}^{3}\right]$ & 14 & 18 & 22 & 26 \\
\hline
\end{tabular}

The foam structure of samples was examined with an Olympus optical microscope. Different settings resulted in various foam structures in the samples. The longitudinal section of the parts provides information about the foamed layer in their centre, while the cross section shows the cell size. Using the microscope images I estimated the average cell size by looking at 50-50 cells. I made an estimate for all cells using the volume of the foamed part and the cell size (taking into consideration of the density of the raw material and the foaming gas).

Mechanical properties were determined with a three-point bending test with a Zwick Z020 universal testing machine. Testing was performed at room temperature with the following technological parameters: supporting pin distance: $\mathrm{L}=28 \mathrm{~mm}$, loading speed: $\mathrm{v}=10 \mathrm{~mm} / \mathrm{min}$. 


\section{Results}

\subsection{Foam structure}

Table 4. contains the main characteristics of the foamed layer and the cells, and Fig.1. shows the various microscope images at various holding pressures.

Table 4. Foam layer properties at different holding pressures

\begin{tabular}{|c|c|c|c|}
\hline Holding pressure profile & High & Medium & Low \\
\hline Average cell size [ $\boldsymbol{\mu m}$ ] & 301 & 237 & 222 \\
\hline No. of all cells (estimated) & 3837 & 17013 & 24807 \\
\hline Volume ratio of foamed layer [\%] & 49 & 62 & 66 \\
\hline Average mass of samples [g] & 15,33 & 15,19 & 14,9 \\
\hline
\end{tabular}

Using high holding pressure the volume ratio of the foamed layer is $50 \%$, and few large cells were produced $(300 \mu \mathrm{m} / 4000)$, at medium holding pressure the foamed layer is $62 \%$ and more $(17000)$ smaller cells $(240 \mu \mathrm{m})$ were produced, while at small holding pressure the ratio of foamed layer was largest $(66 \%)$ and also this produced the smallest size and largest number of cells $(220 \mu \mathrm{m} / 25000)$. This can be attributed to the amount of material injected into the mould: using higher holding pressure more melt enters the mould cavity, a higher internal pressure is created and this inhibits the growing of foamed layer more. Also, the forming cells can spread less so the little cavities connect and form larger cavities, which results in fewer but larger cells inside the product.

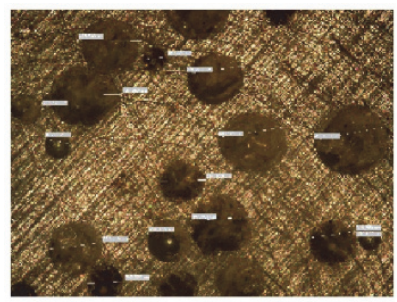

a)

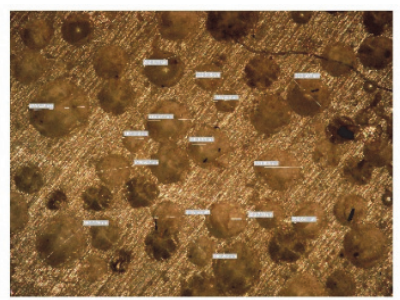

b)

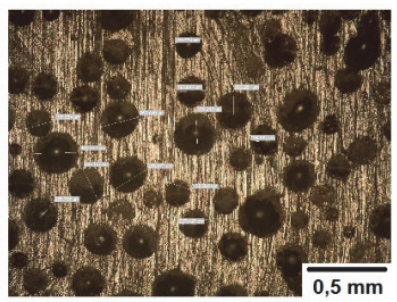

c)

Figure 1. Cell structure forming at high (a), medium (b), and low (c) holding pressure

Table 5. includes the properties of the foam structure, and Fig. 2. shows the microscope images at various switchover points.

Table 5. The properties of the foam layer at various switchover points

\begin{tabular}{|c|c|c|c|c|}
\hline Switchover point [cm $\left.^{3}\right]$ & 14 & 18 & 22 & 26 \\
\hline Average size [Mm] & 231 & 225 & 263 & 295 \\
\hline No. of all cells (estimated) & 16307 & 18146 & 11912 & 7734 \\
\hline Volume ratio of foamed layer [\%] & 66 & 61 & 64 & 62 \\
\hline Average mass of samples [g] & 14,95 & 14,94 & 14,94 & 14,97 \\
\hline
\end{tabular}


Changing the switchover point has the same effect like changing holding pressure: higher values mean less melt in the cavity. The switchover point is normally at the end of the fill phase, but at foam injection moulding it can be before the end of fill. In this case the foaming process causes the melt filling the cavity (and the holding pressure).

When the switchover point was increased, the average size of the cells did not change significantly, the range is about $15 \%$. There is no regularity in the volume ratio of the foamed layer but the change of values within a range of $5 \%$, as opposed to the values in the case of the holding pressure, when the range was much wider, namely $17 \%$.

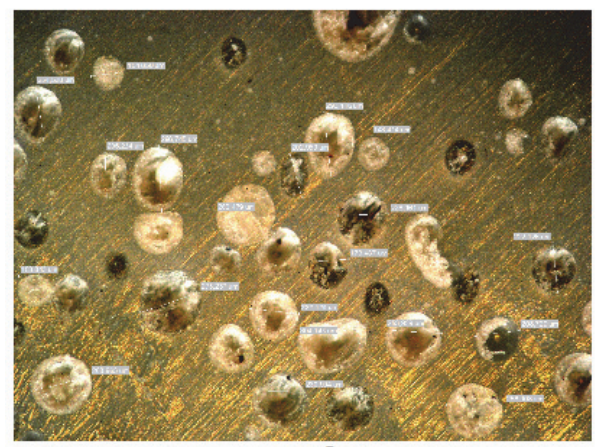

$14 \mathrm{~cm}^{3}$

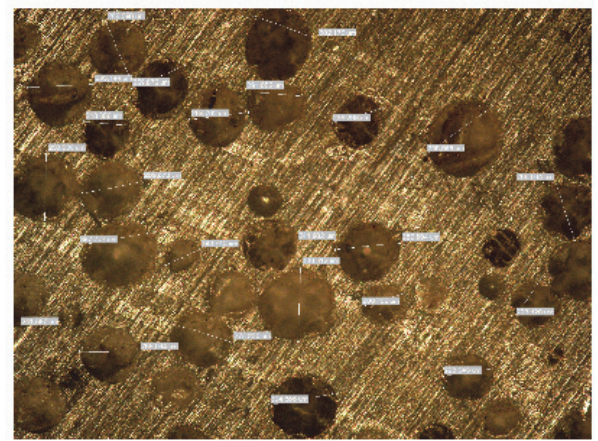

$22 \mathrm{~cm}^{3}$

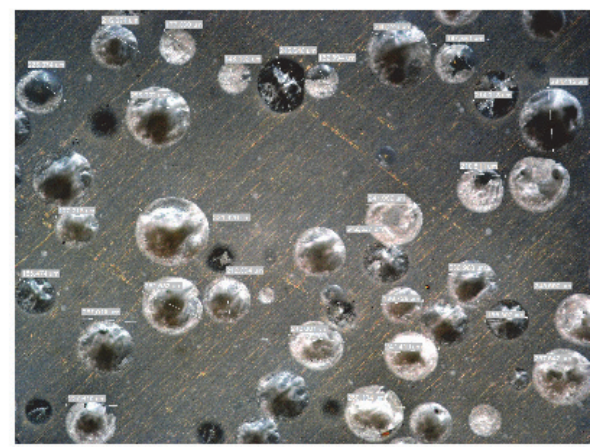

$18 \mathrm{~cm}^{3}$

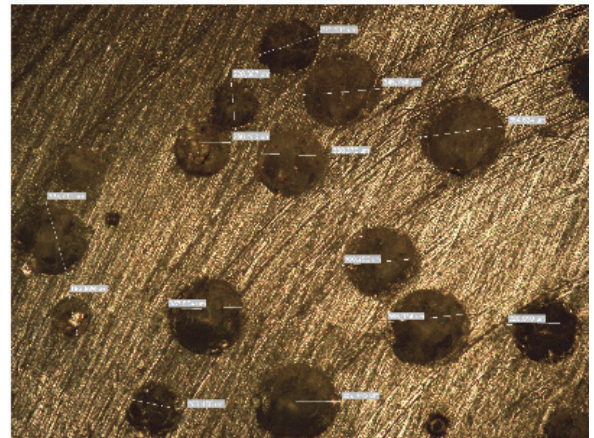

$26 \mathrm{~cm}^{3}$

\section{$\overline{0,5} \mathrm{~mm}$}

Figure 2. Cell structure forming at various switchover points

Fig. 3. shows images of the foam structure of samples made with different holding pressures whereas Fig. 4. shows the foam structures created with different switchover points. 


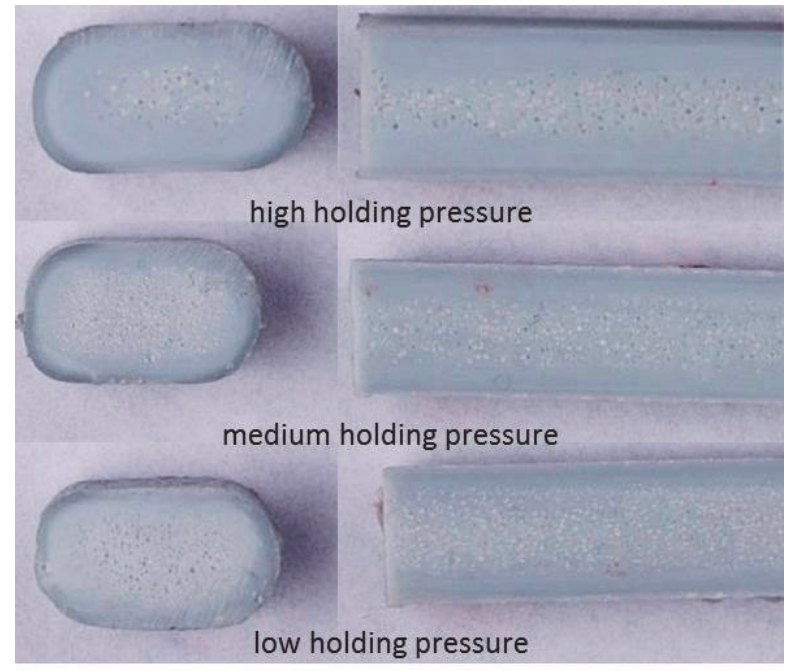

Figure 3. The longitudinal and cross-section of a sample made with different holding pressure

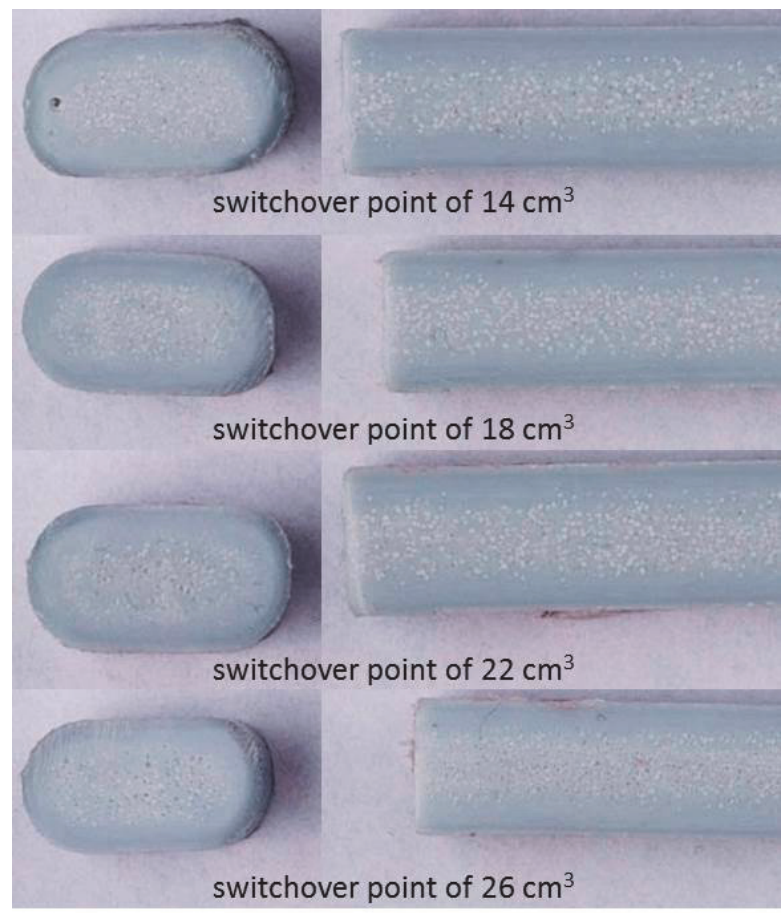

Figure 4. The longitudinal and cross-section of a sample made with different switchover point 


\section{Density}

The densities of the samples at various holding pressure profiles can be seen in Fig. 5. When the holding pressure was high, medium and low, the density of the samples was $1,28 \mathrm{~g} / \mathrm{cm}^{3}, 1,2 \mathrm{~g} / \mathrm{cm}^{3}$, and $1,17 \mathrm{~g} / \mathrm{cm}^{3}$, respectively. Since the volume of the samples is the same, the density is determined by the amount of material injected and the extent of foaming. The goal during foaming is that the appropriate product quality and surface quality is provided by foaming. This can be ensured by decreasing the holding pressure, which results in less material entering the mould, and the mass and consequently the density of the product decreases.

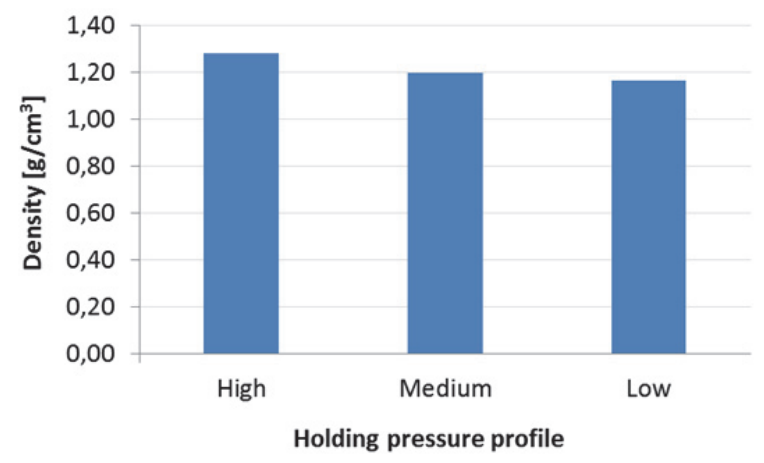

Figure 5. The effect of the holding pressure profile on the density

Fig 6. shows the densities of samples made with different switchover points. As the switchover point was increased, the density of the samples decreased very slightly, by only a few hundredths of $\mathrm{g} / \mathrm{cm}^{3}$. This change can be ignored compared to the effect of holding pressure.

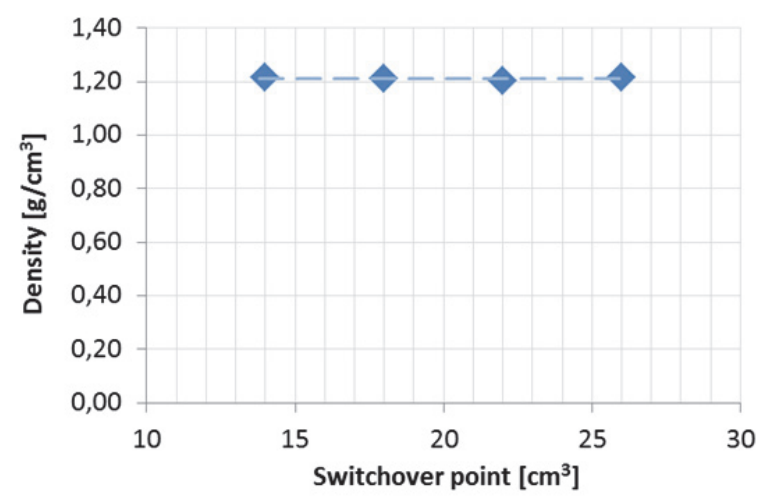

Figure 6. Density as a function of the switchover point 


\section{Mechanical properties}

Fig. 7. shows specific flexural strengths, while Fig. 8. shows specific flexural modulus with three holding pressure profiles. In the case of high holding pressure $35 \mathrm{MPa} /\left(\mathrm{g} / \mathrm{cm}^{3}\right)$ specific flexural strength was measured, while at medium and low holding pressure a nearly identical $25 \mathrm{MPa} /\left(\mathrm{g} / \mathrm{cm}^{3}\right)$ was measured, which is close to $30 \%$ less. The results - compared to the foam structure - show that as the holding pressure decreases, the proportion of the foamed part increases and the average size of the cells, and the specific strength decrease. The same tendency can be observed in the case of modulus values, too. In the case of high holding pressure specific flexural modulus is $750 \mathrm{MPa} /\left(\mathrm{g} / \mathrm{cm}^{3}\right)$, while with medium and low holding pressure specific flexural modulus is close to $400 \mathrm{MPa} /\left(\mathrm{g} / \mathrm{cm}^{3}\right)$.

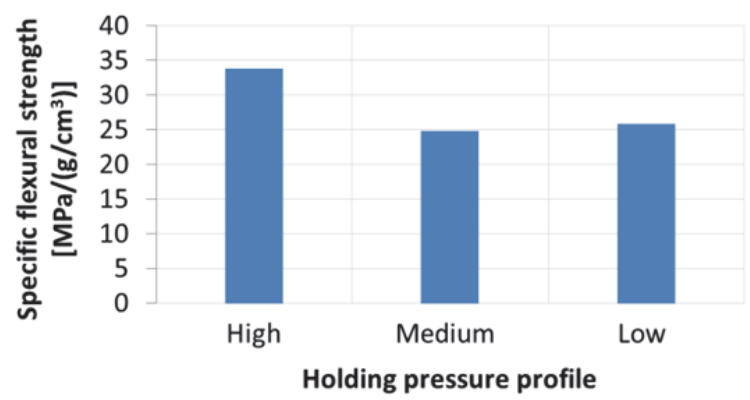

Figure 7. The effect of holding pressure profiles on specific flexural strength

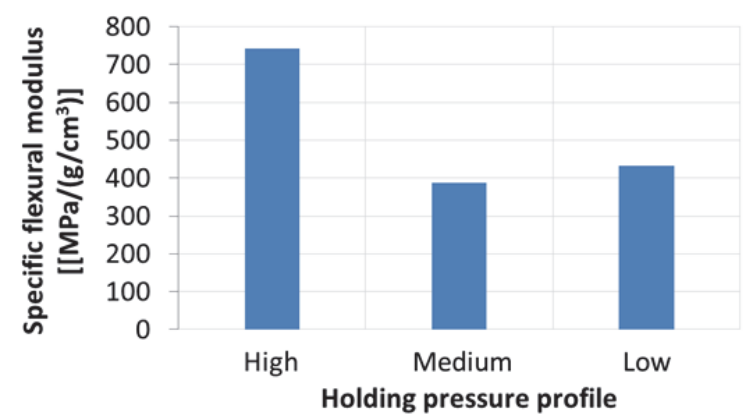

Figure 8. The effect of holding pressure profiles on specific flexural modulus

Fig. 9. shows the specific strength values of the samples, while Fig. 10. shows the specific modulus values of the samples manufactured with various switchover points. The results are similar to the values measured when holding pressure was varied: as the cells grew in the foam structure, the strength also increased: at higher switchover points strength and rigidity were higher. An explanation can be that larger but fewer cells break up the continuity of the structure less and the layer of material is thicker and thus stronger between cells so the part can withstand higher loads. 


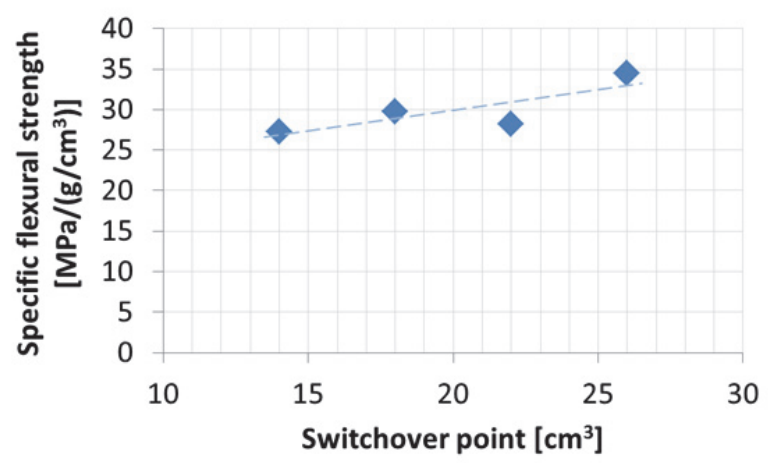

Figure 9. Flexural strength specificized for density as a function of switchover point

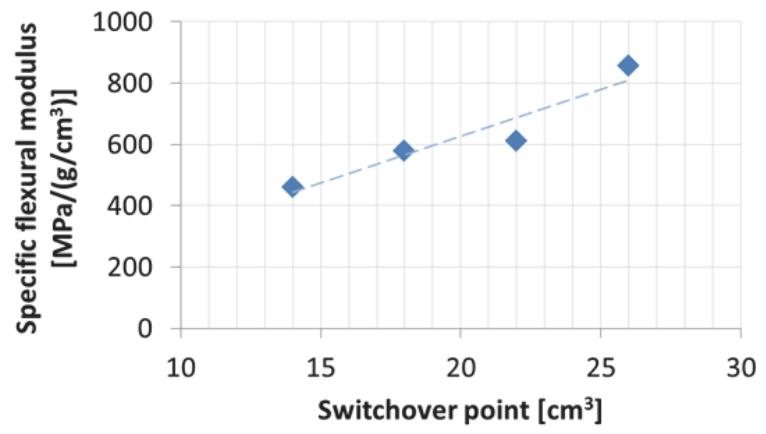

Figure 10. Flexural modulus specificized for density as a function of switchover point

\section{Summary}

The results obtained during the experiments showed that variation in the holding pressure and switchover point both influence the structure and properties of the foamed product considerably. When holding pressure was decreased, the volume ratio of the foamed part in the product increased, and cell size decreased, along with density and strength. When the switchover point was increased no correlation could be observed in the volume ratio of the foamed part but the average size of the cells increased. Density slightly decreased but it was negligible compared to the effect of holding pressure on density. Strength and modulus increased when thinner foamed layer were evolved with larger cells. Based on the results it can be said that density was greatly influenced by variations of holding pressure, while the foam structure was significantly influenced by variations in both holding pressure and switchover point. The mechanical properties can be explained with the foam structure: the thinner foamed layer with larger, but fewer cells break up the continuity of the structure less, the part can withstand higher loads.

\section{Acknowledgement}

The publishing of this paper was supported by the Hungarian Scientific Research Fund (OTKA K109224). 


\section{References}

[1] Buzási, L.: A müanyag csomagolóanyag gyártás helyzete Magyarországon 2010-ben (Status of polymer packaging manufacturing in Hungary in 2010, in Hungarian), Mủanyag és Gumi, vol. 48, no. 11, pp. 405-411, 2011

[2] Welle, F.: Twenty years of PET bottle to recycling - An overview, Resources, Conservation and Recycling, vol. 55, no. 11, pp. 865-875, 2011

DOI:10.1016/j.resconrec.2011.04.009

[3] Dunai, A., Macskási L.: Müanyagok fröccsöntése (Injection molding of polymers, in Hungarian), Lexica Kft., Budapest, 2003

[4] Dogossy, G., Ronkay, F.: Hulladék PET minöségnövelt újrahasznositása (Value-added recycling of PET waste, in Hungarian), A Jövő Jármüve, vol. 8, no 1-2, pp. 47-49, 2013

[5] Schwarz, O., Ebeling, F.-W., Lüpke, G., Schelter, W.: Müanyag-feldolgozás (Polymer processing, in Hungarian), Müszaki Könyvkiadó, Budapest, 1987

[6] Chanda, M., Roy, S. K.: Plastics Technology Handbook, Taylor \& Francis Group, LLC, 2006

[7] Japon, S., Letterrier, Y., Manson, J.-A. E.: Recycling of Poly(Ethylene Terephthalate) Into Closed-Cell Foam, Polymer Engineering and Science, vol. 40, no. 8, pp. 1942-1952, 2000

DOI: $10.1002 /$ pen.11326

[8] Turfa, E., Dogossy, G., Ronkay, F.: Reciklált PET tulajdonságainak javitása reaktiv extruzióval (Improvement of properties of recycled PET with reactive extrusion, in Hungarian), Anyagok világa, vol. 11, no. 2, pp. 50-58, 2013

[9] Dogossy, G., Ronkay, F.: Reciklált PET habositása (Foaming of recycled PET, in Hungarian) In: Csibi-Venczel J: OGÉT 2013: XXI. 21st International Conference on Mechanical Engineering, Romania, Arad, pp. 97-100, 2013

[10] Coccorullo, I., Di Maio, L., Montesano, S., Incarnato, L.: Theoretical and experimental study of foaming process with chain extended recycled PET, Express Polymer Letters, vol. 3, no. 2, pp. 84-96, 2009

DOI: $10.3144 /$ expresspolymlett.2009.12

[11] Di Maio, L., Coccorullo, I., Montesano, S., Incarnato, L.: Chain extension and foaming of recycled PET in extrusion equipment, Macromolecular Symposia, Special Issue: Times of Polymers, vol. 228, no. 1, pp. 185-200, 2005

DOI: 10.1002/masy.200551017 